\title{
Exploring the tourism culinary experiences: an investigation of tourist satisfaction in Ubud
}

\author{
Putu Sucita Yanthy \\ Diploma IV Tourism, Tourism Faculty, Udayana University \\ Denpasar, Indonesia \\ putusucita@unud.ac.id
}

\begin{abstract}
Food has always been part of people"s life,as it has a major role for people. Food can create a memorable experience, especially for tourists who travel with the purpose of seeking new dishes and experiences. Ubud is one of the best destinations in Bali. It has a lot of warung (small eateries) and restaurants. The local food most easily found in this destination ranges from babi guling (suckling pig) to organic food. By drawing a connection between the local food and tourist experience, this research reveals tourist satisfaction and the importance of culinary elements in the development of Balinese dishes in Ubud. In the analysis, the findings are divided into four quadrants describing tourist satisfaction and the importance of culinary elements that refer to nineteen elements. In conclusion, the culinary industry in Ubud has developed fast, and the tourist satisfaction is mainly affected by the efforts of cultural preservation made by the small eateries and restaurants inUbud.
\end{abstract}

Keywords: culinary, local food, Ubud, tourist satisfaction

\section{INTRODUCTION}

Tourism development in a tourist destination is closely related to the cuisine. Competition among tourist destinations in creating new products to attract tourists has led to an increased number of activities in exploring the potentials of the respective tourist destination, especially the local food. A tourism activity which introduces local dishes and beverages, and promotes cultural values is called gastronomy. Gastronomy plays an important role in introducing local food and the uniqueness of the food which is part of the culture. The fact that local food is currently on trend is a marketing opportunity for local food businesses. McDonald's which is one of the favorite fast food restaurants on trend now experiences the influence of the development of local food to meet the needs of global tourists in addition to their biological needs for food.

Human biological needs such as eating and drinking cannot be ignored. Moreover, the idea of mealtime that foreign tourists have makes food and beverages become more important. Without restaurants, bars and catering businesses that meet the needs of tourists, tourism cannot run optimally. The development of this business led to the emergence of many variations of food and beverages so that tourists do not get easily bored. In addition to visiting a destination, tourists also want to taste the local food that may not be provided at the hotel where they are staying. Provision of a variety of dishes is actually part of the local culinary development whose goal is to raise the image of local food to the international level and to compete with the image of food of other countries. Although Balinese food enthusiasts are classified as food-loving tourists or travelers who intentionally visit a destination to taste the local food, they can create opportunities for Bali to introduce its local food.

Today, cafes, restaurants, and warung (small eateries) serving a variety of Balinese, European, and Asian food and beverages such as Chinese, Thai and Vietnamese dishes are easy to find. Now, there are quite many local people who become culinary entrepreneurs, and they come from various social circles. Their motivations also vary. There are also culinary entrepreneurs selling special food that can cure certain diseases and require their customers to consume healthy food. Furthermore, there are culinary businesses that have been operating for generations, which are favorited even by many young people nowadays. Culinary business has added colors to the vibrant tourism in Bali, especially in the area of Ubud. In addition to the dances, painting, and palace, which are the main attractions, now the local cuisine is also one of the attractions in this destination. One of the most popular culinary businesses in Ubud is Warung Bodag Maliah Ubud, which serves organic food such as fried rice, urap (mixed vegetables with grated coconut flesh), salad and specialty drinks from a mixture of herbs such as loloh. The vegetables mostly come from the agricultural land in the surrounding area of the warung. 
Most of the visitors are foreign tourists, and they are suggested to come there by travel agents. Warung Babi Guling Bu Oka is one of the culinary businesses in Ubud, which is famous for its babi guling (suckling pig) among tourists from foreign countries. It attracts the attention of world tourists. In fact, foreign tourists are willing to come all the way just to taste this Balinese food. In addition, there is also Warung Murni, established in 1974. This warung is the first eatery fulfilling the standards of restaurants in Ubud according to The Australian Financial Review Magazine (2015). There is also Warung Bu Mangku Kedewatan, which is famous for its nasi campur (a mixed rice dish topped with a variety of side dishes) in the area of Ubud. The beautiful atmosphere of the Balinese house also adds a new experience for tourists visiting Warung $\mathrm{Bu}$ Mangku.

In order for a Balinese culinary business to be wellknown by both domestic and foreign tourists, hard work is required as it is not easy to present local dishes. By innovating or maintaining the flavors and enhancing the presentation of Balinese food, this local food can compete with international cuisines. Televisions, print media and articles play an important role in introducing local food. Various television shows, especially cooking programs have grown tremendously over the last ten years. Putra (2011) stated that these coverages are quite informative by providing complete information on various kinds of tours, especially culinary tours. The visual form of Balinese food has attracted the attention of tourists, thus making more and more tourists looking for Balinese food. Bartono, Novianto (2005) mentioned that the tourists' interesting local cuisine is part of the shift in style from international to traditional. The serving procedures and the complex menu arrangement usually practiced by European tourists have shifted to a simple and varied menu arrangement with an accentuated local wisdom. This experience is indeed sought after by tourists. Local dishes combined with a traditional-looking atmosphere will certainly attract tourists.

As a tourist destination, Ubud has a potential to introduce Balinese food. Ubud does not only introduce its nature and culture such as Balinese dances and ceremonies. Budaarsa (2012) mentions that one of the famous Balinese dishes in Ubud is babi guling. Many tourists think that their trip is incomplete if they have not tasted babi guling. Even some travel agents have incorporated enjoying babi guling in their tour package. The number of tourists who potentially consume pork, especially babi guling is quite a lot. They are tourists who come from Australia, China, and Taiwan, among others.

Local food is very important in developing the tourism in Ubud. Culinary businesses that specialize in providing food and beverage related services and products are very easy to find. Culinary businesses also cause the emergence of tourist attractions such as food festivals, cultural and agricultural festivals, cooking demonstrations, culinary events, and all culinary related activities that can be a tourist attraction in Bali. One of Ubud food festivals held annually is Ubud Food Festival. There is also Babi
Guling Festival in Gianyar as part of Gianyar Regency's anniversary commemoration.

The development of culinary tourism is inseparable from the role of the tourists who easily share information about local food. The comments on Balinese dishes at the same time promote the food and beverages that characterize every tourist destination in Bali. Culinary businesses also made serious efforts to promote their food through social media. There are also food bloggers who help to promote local food and provide many references to tourists who are eager to enjoy local food. The strong opinions of tourists also become the basis for culinary development as part of Ubud tourism. Various indicators revealed can strengthen the opinion that local dishes are also part of tourist attractions in Ubud.

\section{DISCUSSION}

\subsection{Variety of local dishes in Ubud}

Gianyar is one of the nine regencies in Bali Province which consists of 7 sub-regencies, i.e.: Gianyar, Blahbatuh, Sukawati, Payangan, Tegallalang, Tampaksiring and Ubud sub-regencies. One of the sub-regencies in Gianyar Regency which is the center of cultural tourism development is Ubud. The development of Ubud tourism is the result of the creativity of the legendary figures who developed Ubud ranging from painters to culinary business owners. According to Pitanatri and Putra (2016: 33), since food has been a popular public interest, and eating out has become a lifestyle, the presence of warung (eateries) and Ubud cuisine is recognized as a tourist attraction, even one of the primary attractions or the main reason for tourists to visit Ubud.

The popularity of Balinese cuisine in Ubud is also supported by the development of warung (small eateries) and restaurants that introduce Balinese food. The number of eateries/restaurants in Ubud Sub-regency is 175 (Regional Tourism Office, 2016). Some of them are the legendary and popular restaurants today. Cooking classes are also easy to find in Ubud, some of which introduce Balinese cuisine as well as Ubud community life in the morning by visiting traditional markets for groceries. The popularity of cooking classes in Bali is also praised as quoted from the website ladyironchef.com (2016) which says as follows:

"Cooking classes are incredibly popular at The Island of Gods, and we totally understand why. Most half-day courses include free pick-up from Ubud area and a trip to the local farms and/or markets before students are guided through an interactive experience on how to prepare mouthwatering Balinese classics. And of course, you get to eat whatever you've cooked during the lessons!" (ladyironchef.com, 2016).

It is clear that cooking classes in Bali attract tourists because of the experience they can get during the cooking classes which introduce local ingredients, and more importantly the classic Balinese cuisine. The seven cooking classes introduced on this website are Balinese Farm Cooking School, Casa Luna Cooking School, Jambangan 
Bali Cooking Class, Lobong Culinary Experience Bali, Paon Bali, Payuk Bali Cooking Class and Raw Food Bali.

Local food in Ubud is also introduced through festivals. One of the largest food festivals in Ubud is Ubud Food Festival held annually. This festival has objectives and themes which vary each year, but the main purpose is to explore the local food of the archipelago and specifically introduce Balinese food. Another festival taking the theme of local food in Ubud is Gianyar Culinary Festival, as published on the official website of Gianyar regency tourism board. Anak Agung Ari Brahmanta said that Gianyar Culinary Festival 2017 has a vision of "Towards Healthy, Qualified and Internationally Competitive Gianyar Cuisine". This activity aims to explore the potential of Gianyar cuisine as well as to promote its existence and competitiveness to improve the welfare of the people of Gianyar. This activity is also an effort to develop the tourism sector in Gianyar Regency by providing a wide range of opportunities to the community to be directly involved. Community involvement in Gianyar culinary development through good quality, presentation and service can attract tourists to visit. This is in accordance with the theme of Gianyar Culinary Festival 2017 namely "The Role of Local Cuisine in Gianyar Tourism Industry" so that Gianyar Regency becomes one of the tourist destinations with Gianyar local cuisine as its attraction. This activity also aims to improve the quality of Gianyar traditional cuisine sold in traditional markets. Such aim can be achieved by motivating Gianyar traditional food sellers to improve their service and providing an opportunity for people to actively take part in the development of Gianyar traditional, healthy and quality food.

Ubud and its local food are also internationally known. Ubud Suci Restaurant in Japan is one of the examples of restaurants which apply Balinese cultural related design to its room decor and serves Balinese food menu. Osaka Gate City gives room for this restaurant to grow for the following reasons:

"Ubud is a kind of place that "draws people...who are actively involved in art, nature, anthropology, music, dance, architecture, environmentalism, alternative modalities, and more. This restaurant uses furniture imported from Bali, and its interior décor creates the kind of relaxing and "healing" atmosphere so characteristic of Balinese resorts" (Kosaku, 2010:10).

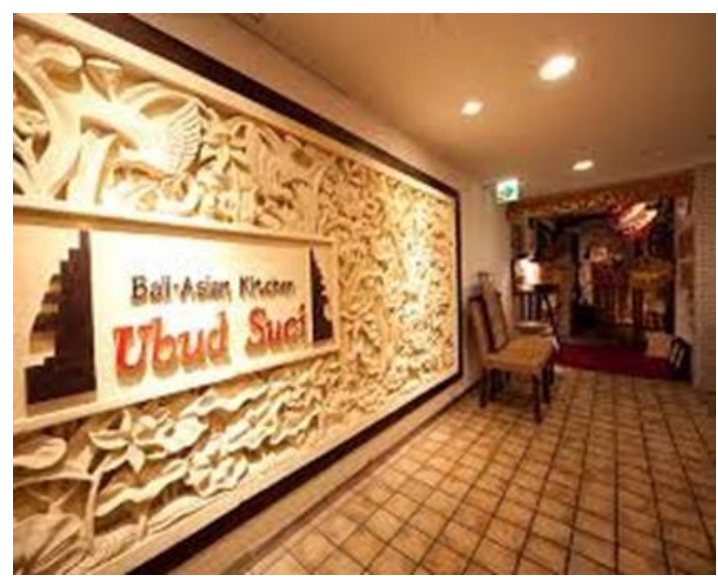

Figure 1. The exterior of Ubud Suci Restaurant in Japan Source:

https://tabelog.com/en/osaka/A2701/A270201/27052628/

Ubud local food is very diverse. Local dishes are served in different ways. Ayam betutu, bebek betutu, lawar, sate lilit, babi guling (suckling pig), and nasi campur (mixed rice) are the local dishes easily found in Ubud. Restaurants and warung (small eateries) in Ubud also serve a variety of local dishes on their menu. Pitanatri and Darma (2016: 125) emphasize the five factors supporting Balinese food in Ubud, they are the increase of millennials tourists, the development of technology and information, eating out as a lifestyle, Balinese culture, and Balinese culinary variations.

Food in Ubud varies from local to fusion food, which is presented to foreign and domestic tourists. Bebek Tepi Sawah Crispy or Grilled Duck is the mainstay of Bebek Tepi Sawah Restaurant, located in Ubud and has branches in Tuban, Kartika Plaza Kuta, and Kuta Beachwalk. The average price of food and drinks at this restaurant ranges from $\mathrm{Rp} 50,000$ to $\mathrm{Rp} 100,000$. This restaurant is open from 10:00 a.m. to 10:00 p.m. and serves Grilled Cock Fighting Chicken. Figure 5.2 below is a crispy duck menu in Bebek Tepi SawahRestaurant.

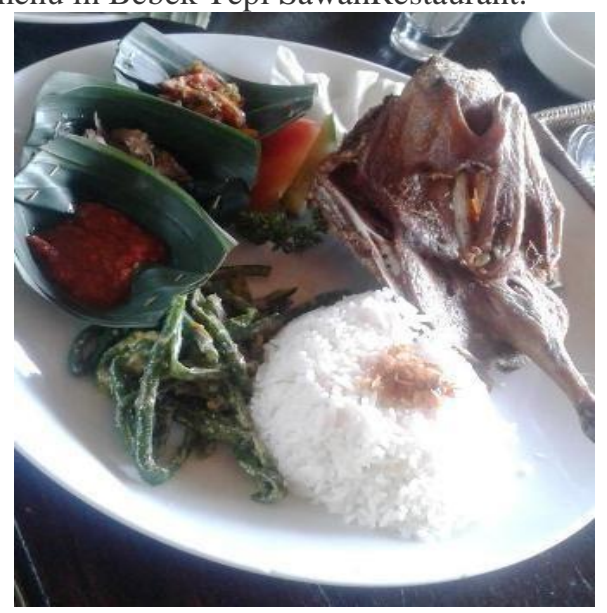

Figure 2. Bebek Tepi Sawah Crispy or Grilled Duck Source: Research Documentation 
The duck-based cuisine is also served in Bebek Bengil Restaurant which was established in 1990. This restaurant is called Bebek Bengil which means dirty duck because when this restaurant was being built, there was a flock of ducks coming from the surrounding rice field. They came in and left their muddy foot-prints on the restaurant floor. This is the inspiration behind the name of the restaurant. The uniqueness of the name of this restaurant as quoted from the website bebekbengil.com is as follows:

One tropical monsoon morning, when the restaurant was very close to being finished (we had the concrete floor down, and the tables in) a flock of ducks from rice fields across the road (...yes, there were rice fields all around us then!) ran quacking and squawking into the restaurant and across the floor and tables. They left their muddy, webbed footprints all over the place. They were our first guests - these Dirty Ducks"'(bebekbengil.co.id).

The crispy fried duck is the restaurant's main stay menu. This is one of the popular dishes among tourists in Ubud. This restaurant, which has several outlets in the South Jakarta Epicentrum, The Breeze Tanggerang, Gandaria City Mall of South Jakarta, MaxxBoxLippo Karawaci, Central Jakarta Menteng, Nusa Dua, Jimbaran, and Tuban has created a Balinese food icon with a crispy duck menu of guaranteed quality. The price of the food in this restaurant ranges from $\mathrm{Rp} \mathrm{55,000} \mathrm{to} \mathrm{Rp} \mathrm{150,000} \mathrm{and} \mathrm{it}$ opens from 10:00 a.m. to 10:30p.m.

Nasi campur (a mixed rice dish topped with a variety of side dishes) is a universal menu that is very easy to find in all corners of the island of Bali. In Ubud area, mixed rice is a legendary dish consisting of various kinds of side dishes and vegetables. A legendary nasi campur menu in Ubud is Nasi Campur Warung Teges Bu Desak and Nasi Campur Ayam Kedewatan. Nasi Warung Teges, which is managed by the family of Ibu Desak, serves home-cooked dishes consisting of processed pork and chicken meat. Cooked with firewood, this mixed rice becomes very special despite its simplicity. The eatery is located in Teges and was established in the 1960s. Figure 5.4 below is nasi campur of WarungTeges.

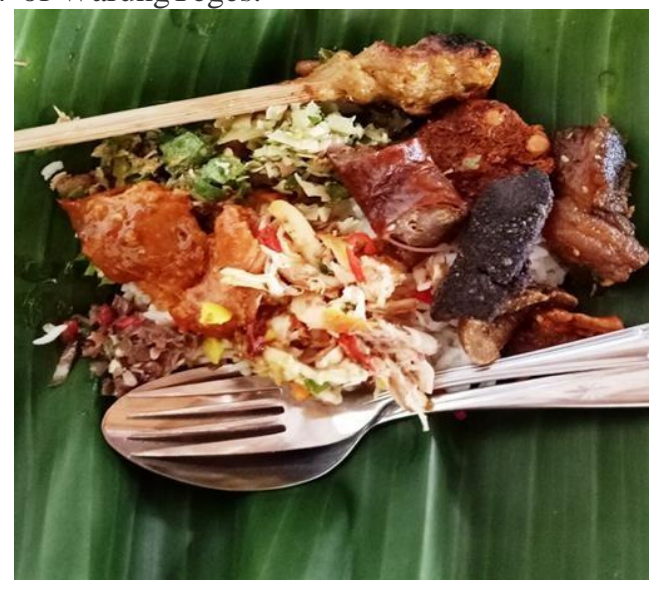

Figure 3. Nasi Campur Warung Teges Source: Research Documentation
Like Warung Nasi Ayam Kedewatan, nasi campur (mixed rice) is the hallmark of this eatery. The difference is only on the side dishes that consist of various processed chicken meat dishes. The owner is Sang Ayu Putu Wija who started her business from a small warung to a small food stall around tajen (cockfighting) places. Another popular Ubud icon is the Nasi Babi Guling Oka, which only opens in Ubud area to keep attracting tourists to choose Ubud as a culinary center. Its three branches are often crowded with visitors from countries such as European countries, Australia and Asian countries who come to taste the increasingly popular pork menu after being covered by Bourdain, a culinary observer who travels to enjoy the unique local food.

Ubud is also famous for its organic dishes served by several famous restaurants such as Warung Sari Bodag Maliah, Clear Café, Bali Buddha, Yellow Flower Cafe, Juice Ja Café and Ubud Organic Farmer's Market (Organic Market).

Healthy eating is easy in Ubud due to the sheer number of spots offering fresh organic cuisine artfully prepared with local seasonal ingredients. You can start your day with a nutrient-packed juice or smoothie, brunch on quinoa bowls and fresh fruit, and enjoy light salads, sandwiches and vegan cuisine for lunch or dinner. And if you want to prepare your organic meals at home, there are even a few spots that sell take-away organic veggies, fruits, nuts, seeds and sauces (ultimate.com).

According to ultimate.com, organic food is not hard to find in Ubud; even vegetarian food enthusiasts can find various organic dishes very easily here. The variety of organic food includes juices, quinoa seeds, fresh fruit, salads, and sandwiches both for lunch and dinner. It is also easy for organic food enthusiasts when they want to prepare their own meals because organic foodstuff is now available and can be bought directly from places such as Sari Organik Farm, which has its own special land to grow organic vegetables and fruit.

Small eateries and restaurants have their own special way of preparing and serving food, like the local people of Ubud with their strong customs and culture in preparing food both for ceremonial needs and symbolization in religious activities. One of the activities that have been carried out from generation to generation is the mebat or paebat (meat chopping) activity performed by the men. This activity may take place during a religious ceremony such as a wedding. One mebat activity that can be documented is during the preparation of a wedding in Puri Ubud. The preparation began with inviting the relatives by delivering jotan or an assortment of dishes arranged according to the status and position of the relatives to be invited. The preparation started at 4 a.m. and finished at 9 a.m. This activity was carried out on 15 August 2017 in the wantilan banjar (community pavilion) of Desa Ubud, where the dishes were prepared for 250 invitees. The women prepared servings of rice and wrapped them with banana leaves. 
The dishes that they prepared included sate lilit, which is a dish of skewered minced pork, chicken, and duck meat. Another dish was lawar, which was prepared using a mixture of ingredients such as young jackfruit flesh, coconut flesh, asparagus beans, and vegetable ferns. This vegetable dish was prepared in phases, starting from adding in the basa genep (complete Balinese spice) paste, madam (shredded boiled meat as replacement of flavor enhancers to add a savory taste to the food), fresh blood, and meat (thinly sliced skin and meat). This activity took place for 5 hours and attracted the attention of the tourists. During the activity, the tourists were welcome to take pictures, ask questions, and even taste the food if they wanted to. The location of the wantilan which is right in the tourist center of Ubud attracted the attention of domestic and foreign tourists. Following are a picture of the mebat activity and a picture of the arrangement of the satay dish to be delivered to relatives in Ubud Village.

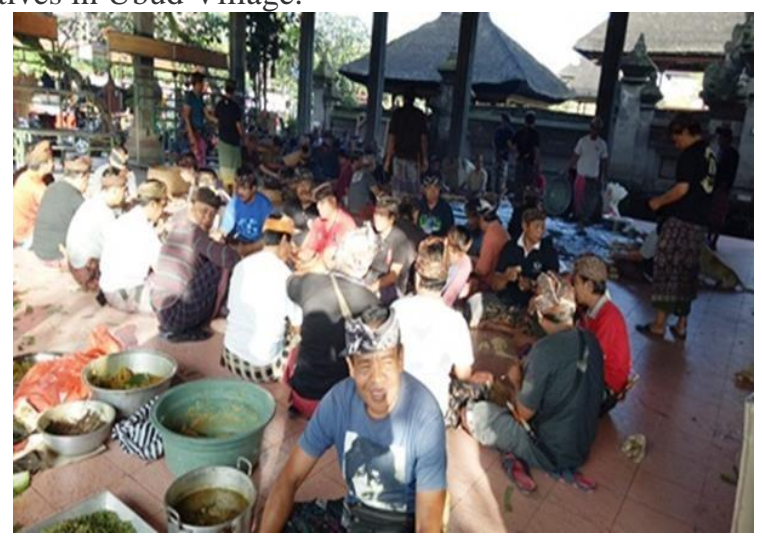

Figure 4. The paebat activity in the wantilan (community pavilion) of Ubud Village

Source: Research documentation

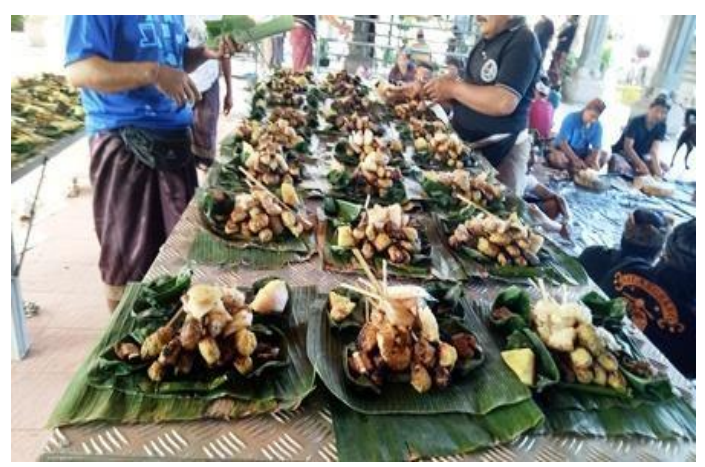

Figure 5. The arrangement of the satay dish

Source: Research documentation

From typical Balinese dishes such as babi guling (suckling pig) and nasi campur (a mixed rice dish topped with a variety of side dishes), food for offerings, to organic food, Ubud offers authentic and fusion dishes. Legendary eateries and restaurants serving fusion dishes are highly sought after by the tourists. The popularity of Balinese cuisine in Ubud is undeniable - the tourists have known Ubud as a culinary haven. To see the development of Ubud's local food from the tourists' view point, following is a discussion of what the tourists have to say, from how they plan their trip to seek a new experience of enjoying the local dishes in Ubud to the indicators that determine the direction of the future development of Balinese cuisine in Ubud.

\subsection{Tourists' Experiences of Ubud's Local Food}

With regard to the tourists' characteristics, they are categorized firstly by their home country. Most of the tourists visiting Ubud come from Australia, Europe, USA, and Asia. 10 of the respondents are Australians, 8 of them are French, and 7 are Americans. The majority of the domestic tourists answered that their nationality is Indonesian, and 34 of them are from Jakarta. Secondly, the respondents are comprised of 50 women and 41 men. Thirdly, the respondents are categorized by their age. There are more respondents by the age of 21-35 years compared to the other age groups, namely the age group of 36-50 years, followed by the age group of 50 years up, which is the lowest in number. Fourthly, categorized by the respondents' occupation, the highest number of the respondents, i.e., 40 respondents, are private employees, 14 respondents are government employees, 12 respondents are students, and 10 respondents are entrepreneurs.

The attractions of Ubud area are the food (30\%), the culture $(17 \%)$, and nature $(16 \%)$. Culinary industry in Ubud has developed very well because of the variety of local dishes that appeal to the tourists. The 87 research respondents stated that their trip was not arranged by a travel agent. If this fact is linked to the age of the respondents which are dominated by those of the age group of $21-35$, it is very clear that they have chosen to plan their own trip in their own way without the help of a tour \& travel agency. Tourists of the age group of 21-35 years are categorized as millennial tourists.

PATA reveals the six travel trends for 2016 as

follows:

"Seeking new experiences, spending more because it's worth it, choosing destinations based on the culture and special offers, staying cool and connected, rising room rates and optimism, managing reputation online," (Visitor electronic bulletin 2016:1-6).

The travel trends for 2016, as explained in the monthly bulletin published by PATA, are that tourists have travel patterns and motivation to visit tourist destinations with the purpose of having a holiday experience that is different from the usual, are willing to spend more, choose to visit destinations with interesting local culture and special offers, and make sure that the hotel they are staying in has air-conditioning and $\mathrm{WiFi}$. The other two trends are the rising room rates and the importance of online reviews. With the tourists having easy access to information on the destinations that they will visit, there is a great opportunity for destinations to promote interesting attractions, for example by introducing the local cuisine. Local cuisine is a reflection of the culture of the place that the tourists visit, and it is a unique experience for the tourists to taste food that is appetizing. The easy access the tourists have to 
information makes their travel easy, and therefore today they have a tendency to arrange their trip themselves without contacting a travel agency.

The sources of information on Balinese cuisine include friends with a percentage of $49.4 \%$ and websites with a percentage of $35.1 \%$. $92.3 \%$ of the respondents answered that they had tried Balinese cuisine but $54.9 \%$ of the respondents did not always choose Balinese dishes from the menu offered by the warung (small eateries) and restaurants in Ubud because there is a variety of dishes that are a fusion of Balinese cuisine and dishes from other countries such as Thailand and Europe. The babi guling (suckling pig) dish is a favorite in Ubud area. 36.2\% of the respondents choose this dish as their favorite, because in addition to the dish being the icon of Bali as the most favorited local food, the eatery Babi Guling Oka in Ubud is also very popular among the tourists who like Balinese dishes.

According to the questionnaire results, the tourists' perceptions of the development of tourism are positive $(59.7 \%)$. Their statements can be linked to the various types of restaurants in Ubud area and a number of popular and legendary small eateries and restaurants. They are categorized from small eateries with affordable prices to fine dining restaurants, with a variety of dishes from babi guling to vegetarian and organic health food. There are also cafes and bistros with special spots for taking pictures, known as Instagenic spots. The tourists also stated that the restaurants and small eateries in Ubud offer local dishes on their menu. As many as $36.3 \%$ of the tourists with positive perceptions stated that local dishes such as nasi campur, babi guling, satay lilit, etc. are easy to find in Ubud. The aspect of the eateries and restaurants in Ubud that the tourists are mainly concerned with is cleanliness, as stated by as many as $29.7 \%$ of the respondents.

The following factors will show the tourists' level of satisfaction as measured before the tourists' visit, during their visit, and after their visit to Ubud, with an emphasis on complaint handlings. These factors are the reference benchmarks for the development of Ubud as a culinary destination. Tourists' satisfaction with the quality of Balinese culinary tourism in Ubud is formulated using the IPA (Importance Performance Analysis) which functions to measure the responses on the attribute importance and the satisfaction of the tourists visiting Ubud. The indicators of tourists' satisfaction with and attribute importance of Balinese culinary tourism are shown in a Cartesian diagram which consists of four segments defined from one another by two lines intersecting perpendicularly at the $\mathrm{X}$ and $\mathrm{Y}$ coordinate origin. Along the $\mathrm{X}$ axis (the horizontal axis) are the values of the importance degree, and along the $\mathrm{Y}$ axis (the vertical axis) are the values of satisfaction level. The first step to take is calculating the mean of the values of the importance degree and the mean of the values of satisfaction level, and then draw them in the Cartesian diagram. The results of the analysis are as follows.
Table 1. The Means of the Values of Importance Degree and Satisfaction Level on the Indicators Affecting the Tourists' Perceptions of the Culinary Tourism Development in Ubud

\begin{tabular}{|c|c|c|c|c|c|}
\hline \multicolumn{6}{|c|}{$\begin{array}{c}\text { Remarks } \\
\text { Mean }=\mathrm{X}(\mathbf{3 . 8 6}), \mathrm{Y}(\mathbf{4 . 1 8})\end{array}$} \\
\hline No. & $\mathbf{X}$ & $\mathbf{Y}$ & No & $\mathbf{X}$ & Y \\
\hline 1 & 3.65 & 4.05 & 11 & 4.36 & 4.58 \\
\hline 2 & 3.95 & 4.57 & 12 & 4.19 & 4.33 \\
\hline 3 & 4.08 & 4.31 & 13 & 3.92 & 3.85 \\
\hline 4 & 3.55 & 3.75 & 14 & 4.14 & 4.42 \\
\hline 5 & 4 & 4.32 & 15 & 4.01 & 4.32 \\
\hline 6 & 3.77 & 4.15 & 16 & 3.97 & 4.11 \\
\hline 7 & 3.69 & 4.07 & 17 & 3.8 & 4.11 \\
\hline 8 & 4.11 & 4.55 & 18 & 3.75 & 4 \\
\hline 9 & 4.14 & 4.34 & 19 & 3.9 & 4.2 \\
\hline 10 & 3.78 & 4.02 & Mean & 3.93 & 4.21 \\
\hline
\end{tabular}

Source: Results of research analysis.

\section{Description}

1. Information about the local warung (eateries)/restaurants through travel agencies, hotels, brochures, and magazines.

2. Information about the local eateries/restaurants through websites/online tourist information.

3 . The popularity of the eateries/restaurants because of the Balinese dishes served.

4. The popularity of the eateries/restaurants because of the owner.

5. Ease of access to reach the eateries/restaurants.

6 . The cozy atmosphere of the eateries/restaurants, and entertaining attractions.

7. Building architecture and the setup of eateries/restaurants.

8. Quality of service by the restaurants' staff serving Balinese dishes.

9. The staff of eateries/restaurants promoting Balinese dishes

10. Direct involvement of the business owner in serving the customers

11. Appearance, attitude, and friendliness of the eateries/restaurants' staff in serving Balinese dishes.

12. The eateries/restaurants being oriented towards offering a variety of Balinese menu packages.

13. The eateries/restaurants offering various activities such as cooking lessons and other activities.

14. Appropriateness of the cost paid with the tourists" satisfaction.

15. Variety, quality, and portions of Balinese dishes.

16. Innovations of Balinese dishes and their adaptation to other types of cuisines.

17. Collaboration between the eateries/restaurants and the local community in developing the local cuisine.

18. Participation of the eateries/restaurants in festivals or culinary attractions.

19. Handling of consumers' complaints. 
Each of the indicators is distributed into four segments or quadrants in the Cartesian diagram and there are two variables that are represented by the letter $\mathrm{X}$ and $\mathrm{Y}$. Based on the comparison between the two variables, the levels of respondents' perceptions can be obtained. For a closer look, below is the Cartesian diagram showing the indicators affecting the priority scales.

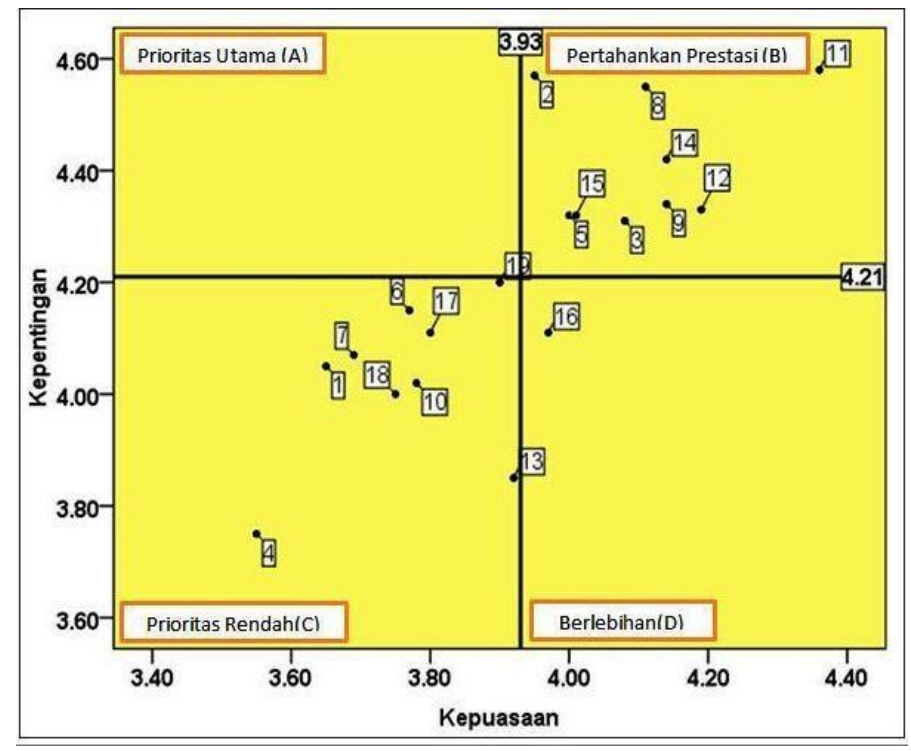

Figure. 5 Cartesian Diagram - the indicators affecting the tourists' opinions of the culinary development in Ubud

\section{Quadrant A}

Quadrant A shows that none of the culinary elements in Ubud is a priority to the tourists. From this, it can be concluded that the elements for the Balinese culinary development do not affect or are not considered important by the tourists, and do not give satisfaction to the tourists. These elements should receive special attention from the parties engaged in the culinary development in Ubud.

\section{Quadrant B}

Quadrant B shows that the elements should be maintained in the culinary development in Ubud. These elements are considered to be very important and satisfying. The elements or indicators are as follows:

1. Information about the eateries/restaurants accessed through websites/online tourist information.

2. The popularity of eateries/restaurants because of the

Balinese dishes served.

3. Ease of access to reach the eateries/restaurants.

4. The quality of service of the restaurant staff serving the

Balinese dishes.

5. The staff of eateries/restaurants promoting Balinese dishes on the menu.

6. Appearance, attitude, and friendliness of the eateries/restaurants' staff in serving Balinese dishes.

7. The eateries/ restaurants are being oriented towards offering a variety of Balinese menu packages.

8. Appropriateness of the cost paid with the tourists' satisfaction.
9. Variety, quality, and portions of Balinese dishes.

\section{Quadrant C}

Quadrant C shows several elements that do not have any significant influence on the tourists because they are considered to be unimportant and not unsatisfying, namely:

1. Information about the eateries/restaurants from travel agencies, hotels, brochures, and magazines.

2. The popularity of the eateries/restaurants because of the owner.

3. The cozy atmosphere of the eateries/restaurants, and entertaining attractions.

4. Building architecture and the setup of eateries/restaurants.

5. Direct involvement of the business owner in serving the customers.

6. The eateries/restaurants offering various activities such as cooking lessons and other activities.

7. Collaboration between the eateries/restaurants and the local community in developing the local culinary products.

8. Participation of the eateries/restaurants in festivals or culinary attractions.

9. Handling of consumers' complaints.

\section{QuadrantD}

Quadrant D shows the attributes that are not very important and whose execution is considered to be excessive. These attributes are considered to be not very important, but very satisfying, namely innovations of Balinese dishes and their adaptation to other types of cuisines. The factors occupying this quadrant are innovations of Balinese dishes and their adaptation to other types of cuisines.

Based on the IPA analysis, the elements occupying the quadrant (c) need special handling, namely information about the eateries/restaurants from travel agencies, hotels, brochures, and magazines, popularity of the eateries/ restaurants because of the owner, cozy atmosphere of the eateries/restaurants and entertaining attractions, building architecture and the setup of eateries/ restaurants, direct involvement of the business owner in serving the customers, the eateries/ restaurants offering various activities such as cooking lessons and other activities, collaboration between the eateries/restaurants and the local community in developing the local cuisine, participation of the eateries/restaurants in festivals or culinary attractions, and handling of consumers' complaints. In the area of the quadrant (d), the element that is considered to be excessive in its execution is the innovations of Balinese dishes and their adaptation to other types of cuisines. This should be taken into our consideration because local food is the identity of a region; if it is overly innovated then the original elements of Balinese food will diminish.

\section{CONCLUSION}

Balinese cuisine, especially the authentic Balinese food, has a high appeal, especially in the Ubud area. Foreign and domestic travelers are always curious and 
interested to try local food. Balinese dishes are rich in flavors, and will always awake none's appetite in whatever style they are served. However, today food presentation is a point of interest for culinary enthusiasts, and therefore culinary business owners try to present dishes well so that they look appetizing. These efforts are what they call fusion, as most culinary businesses in Bali adapt their menus to the tourists's taste while still retaining a touch of Balinese flavor.

From the priority scale, the conclusion that can be drawn is that the culinary tourism in Ubud should be developed without neglecting the local identity, as according to the tourists the current efforts in culinary adaptation and innovation are considered to be over the top, as can be observed from the numerous Balinese dishes being attractively presented minus the distinctiveness of the local identity. In addition, what culinary businesses commonly do is modify the standard flavors of Balinese dishes to adapt to the tourists' taste. This point should be used as the basis of consideration for the development of the local Balinese cuisine so that the culinary tourism will always preserve the consistency with and commitment in maintaining the local identity of Balinese dishes.

\section{REFERENCES}

[1]. Bartono, Novianto. 2005. Today's Business Ethnic: Langkah-Langkah Strategis Menerapkan Etika dalam Bisnis dan Pariwisata. Jakarta: PT Elex Media Komputindo.

[2]. http://www.ladyironchef.com/2016/05/bali-cookingclases/

[3]. Yoshino, Kosaku. 2010. Malaysian Cuisine: A Case of Neglected Culinary Globalization. In Globalization, Food and Social Identities in the Asia Pacific Region, ed. James Farrer. Tokyo: Sophia University Institute of Comparative Culture. URL:

http://icc.fla.sophia.ac.jp/global\%20food\%20papers/ $\underline{\mathrm{html} / \text { yoshino.html }}$

[4] Putra, I Nyoman Darma. 2014. "Empat Srikandi Kuliner Bali: Peran Perempuan Dalam Pembangunan Pariwisata berkelanjutan".JUMPA; Vol. 1, No. 1, pp. 65-94.

[5] The Australian Financial Review.2014. "World on plate a Fusion Revolution is firing up Ubud's fine dinning scene", Sumber:https://www.murnis.com/reviews

[6] Diah Pitanatri,I Nyoman Darma Putra. 2016. Wisata kuliner: atribut baru destinasi Ubud, JagatPress

[7] PATA.2016. Visitor electronic bulletin

[8] Regional Tourism Report of Gianyar Regency. 2016 